2016

\title{
Banning Bribes Abroad: U.S. Enforcement of the Foreign Corrupt Practices Act
}

Ellen Gutterman

Follow this and additional works at: http:// digitalcommons.osgoode.yorku.ca/olsrps

Part of the Law Commons

\section{Recommended Citation}

Gutterman, Ellen, "Banning Bribes Abroad: U.S. Enforcement of the Foreign Corrupt Practices Act" (2016). Osgoode Legal Studies Research Paper Series. 125.

http://digitalcommons.osgoode.yorku.ca/olsrps/125 


\section{Banning Bribes Abroad: U.S. Enforcement of the Foreign Corrupt Practices Act}

\section{Introduction}

Notwithstanding its support of a variety of corrupt and kleptocratic authoritarian regimes throughout the Cold War, the United States has been at the forefront of international efforts to combat corruption in the global economy for almost forty years. Its chief legal instrument throughout has been the Foreign Corrupt Practices Act (FCPA). ${ }^{1}$ Enacted in 1977 and twice amended - in 1988 and again in 1998 - the FCPA prohibits corrupt payments by individuals and companies to foreign government officials for the purpose of "securing any improper advantage" in obtaining or retaining business abroad. Jointly enforced by the criminal division of the Department of Justice (DOJ) and the enforcement division of the Securities Exchange Commission (SEC), the FCPA applies to any U.S. person (individual or entity) as well as to any non-U.S. persons with securities registered in the U.S. ("non-U.S. issuers") and their employees engaged in proscribed acts outside the territory of the United States. In short, the FCPA bans bribery abroad by U.S. persons and some non-U.S. persons alike.

Over the past decade, enforcement of this ban by the United States has surged. FCPA enforcement has yielded record fines and disgorgements of profit totaling more than $\$ 5$ billion, exacted prison sentences up to 15 years for individuals, and created far-reaching consequences for anti-bribery enforcement in other jurisdictions. As FCPA enforcement has grown, so has the corpus of media analysis and legal scholarship - particularly from international business lawyers devoted to examining, explaining, and commenting on this legislation and its impact on business ${ }^{2}$.

1 The Foreign Corrupt Practices Act of 1977, as amended, 15 U.S.C. $\S \S 78 d d-1$, et seq.

2 Eric C Chaffee, "From Legalized Business Ethics to International Trade Regulation: The Role of the Foreign Corrupt Practices Act and Other Transnational Anti-Bribery Regulations in Fighting Corruption in International Trade" (2013) 65 Mercer Law Rev 701; Sarah Bartle, Chris Chamberlain \& Brian Wohlberg, "Foreign Corrupt Practices Act" (2014) 51:4 Am Crim Law Rev 1265; John Ashcroft \& John Ratcliffe, "The Recent and Unusual Evolution of an Expanding Fcpa" (2012) 26:1 Notre Dame J Law Ethics Public Policy 25; Stuart Deming, The Foreign Corrupt Practices Act and the New International Norms, 2nd Edition ed (American Bar Association, 2011); Daniel Patrick Ashe, "The Lengthening Anti-Bribery Lasso of the United States: The Recent Extraterritorial Application of the U. S. Foreign Corrupt Practices Act" (2005) 73:6 Fordham Law Rev 2897. 
Not surprisingly, most of the FCPA literature includes considerable consternation among businessoriented observers that the enforcement agencies have become "overzealous" in their focus on the FCPA, which has sharply increased the risks and altered the calculus of international commercial ventures ${ }^{3}$.

Taking a close look at the data on FCPA enforcement actions since 2003, the present study reveals two notable trends. ${ }^{4}$ The first is, indeed, the trend of increased enforcement. As others have noted, there have been significantly more enforcement actions in the past decade than ever before against both corporations and individuals - yielding greater penalties. Expanded enforcement has proceeded especially on an unprecedented reliance on deferred-prosecution and non-prosecution agreements to exact penalties and ensure the implementation of robust corporate compliance regimes among those suspected of foreign bribery. The impact of these "diversion agreements" on FCPA enforcement is, among other ramifications, such that the trend of expanded enforcement is likely to continue.

The second notable trend is the application of increasingly expansive notions of extraterritorial jurisdiction in the enforcement of the FCPA. Over the past decade US agencies have increasingly enforced the FCPA against foreign issuers and foreign nationals for behaviour undertaken outside the territory of the United States. In tandem with the use of diversion agreements - which replace costly trials but also preclude the production of judicial decisions and the development of case law on such matters - the enforcement agencies have expanded the theories of jurisdiction upon which they base their claims to authority over bribery abroad. Interestingly, they have been doing so in ways that run counter to trends in other areas of law where U.S. courts have been limiting the extraterritorial application of American law. Extraterritorial jurisdiction (ETJ) extends the scope and reach of national laws into global regulatory environments and into other sovereign territories. Long a scholarly focus within specific bodies of law in international trade and economic law - such

${ }^{3}$ Kristin Isaacson, "Minimizing the Menace of the Foreign Corrupt Practices Act" (2014) 2014 Univ Ill Law Rev 597; Mike Koehler, Big, Bold, and Bizarre: The Foreign Corrupt Practices Act Enters a New Era, SSRN Scholarly Paper ID 1971021 (Rochester, NY: Social Science Research Network, 2011); Jordan Weissmann, "The Corruption Law That Scares the Bejesus Out of Corporate America", (25 April 2012), online: The Atlantic <http://www.theatlantic.com/business/archive/2012/04/the-corruption-law-that-scares-thebejesus-out-of-corporate-america/256314/\#>.

${ }^{4}$ Enforcement data throughout are drawn from Shearman \& Sterling LLP's "FCPA Digest of Cases" Philip Urofsky, ed, FCPA Digest of Cases and Review Releases Relating to Bribes to Foreign Officials under the Foreign Corrupt Practices Act of 1977 (Shearman \& Sterling LLP, 2014). as well as from the web sites of the DOJ "FCPA and Related Enforcement Actions", (2014), online: U S Dep Justice <http://www.justice.gov/criminal/fraud/fcpa/cases/a.html>. and SEC "SEC Enforcement Actions: FCPA Cases", (2014), online: US Secur Exch Comm <http://www.sec.gov/spotlight/fcpa/fcpa-cases.shtml>.. 
as anti-trust, export control, and securities regulation - ETJ increasingly is the subject of attention and controversy in international legal scholarship concerning human rights, transnational crime, and other issues ${ }^{5}$. This literature has yet to grapple with extraterritorial jurisdiction in anticorruption law, which is quickly becoming a defining feature of the global governance of corruption.

The twin trends of expanded FCPA enforcement and expanded jurisdiction in FCPA enforcement, therefore, are important not just for practitioners and commercial enterprises seeking to avoid running afoul of the law. Such active extra-territorial enforcement of the US foreign corrupt practices act also carries important implications in the global governance of corruption, generally. It exemplifies the ways in which American legal frameworks, politics, and public policy are being actively exported by U.S. enforcement authorities, thereby shaping and constraining global politics in both intended and unintended ways. Beyond legal questions concerning the proper scope of jurisdiction, these practices raise important questions concerning expressions of power in world politics and the theory and practice of International Relations. Under what circumstances are states more or less likely to apply and enforce law across borders? What explains the scope and limitations of ETJ in various areas of international law, in theory and in practice? What are the implications of ETJ for state sovereignty and autonomy, and for the efficacy and legitimacy of global regimes of governance, in a range of issue areas? In the case of US enforcement of the FCPA, increasingly expansive notions of jurisdiction promote U.S. foreign policy and domestic political and economic objectives and serve to shape the global regime of anti-corruption in light of those objectives. In crucial ways, the underlying resource in FCPA enforcement is hegemonic American power, which ultimately challenges norms of sovereignty, legitimacy, justice, cooperation, national interests, as well as efficacy in global governance.

This paper draws out and explains these themes in three main parts. Part one provides the background and global context of US enforcement of the FCPA, moving beyond the U.S. regulatory environment of the FCPA to highlight the global governance of bribery and corruption and, particularly, the internationalization of the FCPA in the 1990s via the Organization for Economic Cooperation and Development (OECD). Part two draws on data from a variety of government, intergovernmental, non-governmental, and private sector sources to demonstrate and discuss the two key trends in FCPA enforcement over the past decade, namely the expansion of enforcement -

${ }^{5}$ Cedric Ryngaert, Jurisdiction in International Law (Oxford University Press, 2008); Mark Gibney, "Toward a Theory of Extraterritoriality" (2010) 95 Minn Law Rev Headnotes 81; Paul Arnell, Law Across Borders: The Extraterritorial Application of United Kingdom Law (New York: Routledge, 2012); Kal Raustiala, Does the constitution follow the flag?: The evolution of territoriality in American law (Oxford: Oxford University Press, 2009); Marko Milanovic, Extraterritorial Application of Human Rights Treaties (Oxford University Press, 2011). 
including the expanded use of diversion agreements in enforcement - and the expansion of jurisdiction - including recent illustrative cases. Part three discusses the implications of these trends, in two dimensions. The first, citing research in political science and international relations, shows how US enforcement of the FCPA has been instrumental in promoting anti-corruption policies and enforcing anti-corruption legislation globally, and in banning bribes abroad. At the same time, the application of the FCPA across borders - to persons and circumstances occurring outside the territory of the United States -both shapes and constrains international anti-corruption efforts in ways that may be unintended but which may nevertheless run counter to effective governance practices and meaningful anti-corruption reform in the global economy. Three aspects of FCPA enforcement in particular constrain the broader goals of global anti-corruption governance: the narrow conception of corruption upon which the FCPA is based; the strategic trade frame which underlies the FCPA's internationalization; and the legitimacy problems these suggest. Building on established interdisciplinary International Law/International Relations (IL/IR) scholarship, the paper concludes with suggestions for such interdisciplinary work on the global governance of bribery and corruption, and calls for a new IL/IR agenda of research on extraterritorial jurisdiction in international law, generally.

\section{Background and Context: The Global Anti-Corruption Regime}

\section{The Global Governance of Bribery and Corruption}

Corruption emerged as a primary item on the global governance agenda, as well as on the agenda of U.S. foreign policy, beginning in the mid-1990s. ${ }^{6}$ Most contemporary research on corruption - most simply defined as the abuse of public power for private gain, but involving complex patterns and wide-ranging manifestations - reveals that corruption is a harmful problem, causing damaging outcomes across a range of concerns in the international political economy -which makes its control an important focus of international policy. Corruption distorts markets, disrupts international flows of goods and capital, and reduces economic growth. Some estimates show that the cost of corruption amounts to more than 5\% of global GDP (US\$ 2.6 trillion) with more than US\$ 1 trillion paid in bribes each year ${ }^{7}$. In international business, bribery impedes fair

\footnotetext{
${ }^{6}$ This section draws upon Ellen Gutterman, "Corruption in the Global Economy" in Greg Anderson \& Christopher John Kukucha, eds, Int Polit Econ (Don Mills, Ont.: Oxford University Press Canada, forthcoming).

${ }^{7}$ World Economic Forum, "Global Agenda Council on Anti-Corruption \& Transparency 2013", online: Glob Agenda Counc Anti-Corrupt Transpar 2013 World Econ Forum <http://www.weforum.org/content/global-agenda-council-anti-corruption-transparency-2013>;
} 
market competition and obstructs liberal international trade. By paying bribes corrupt firms gain an unfair business advantage against more efficient firms and raise the cost of doing business for all. The cost of bribes can escalate, and the advantages gained become increasingly unreliable. Insofar as corruption includes the "capture" of public institutions and regulatory bodies by powerful private interests, it has been identified by some as the key underlying cause of the $2007 / 2008$ global financial crisis ${ }^{8}$.

Corruption also impedes sustainable development and perpetuates poverty. Resources intended to assist development and alleviate global poverty are often diverted through corruption and aid does not reach its intended recipients. Corruption can lead to indiscriminate lending for development projects which fill the pockets of bureaucrats rather than the stomachs of the hungry. In The White Man's Burden William Easterly notes how trillions of dollars of foreign aid spent on grandiose development projects since the 1960s have been wasted, and billions outright stolen due to corruption, causing costs to democracy, human rights, global health, and the environment 9. Corruption also degrades the quality of goods and services provided, with sometimes catastrophic social costs - substandard housing and public health systems, substandard medicine and health care, dangerous industrial conditions, and vulnerability to natural disasters. As the anti-corruption NGO Transparency International emphasizes, the poor and disempowered suffer the most from corruption, which often goes hand in hand with violence and persistent poverty 10 .

Corruption undermines democracy, human rights, and human security. It feeds political instability, sustains inequality, undermines public trust in society's institutions of governance, leads to social unrest, and supports the proliferation of transnational crime. Corrupt and criminal organizations can supplant government authority, creating a new type of violent and authoritarian social control that is destructive of communities and human rights ${ }^{11}$. Corruption remains an

The World Bank, "The Costs of Corruption", (8 April 2004), online: <http://go.worldbank.org/LJA29GHA80>; For a skeptical view see Chris Blattman, "Corruption and development: Not what you think?", (5 November 2012), online: Chris Blattman Int Dev Polit Econ Policy <http://chrisblattman.com/2012/11/05/corruption-and-development-not-what-youthink/>.

8 Daniel Kaufmann, "Corruption And The Global Financial Crisis", (27 January 2009), online: Forbes <http://www.forbes.com/2009/01/27/corruption-financial-crisis-businesscorruption09_0127corruption.html>.

${ }^{9}$ William Easterly, The white man's burden (London: Penguin Books, 2007).

10 Transparency International, "What we do", (2013), online: Transpar Int - Glob Coalit Corrupt $<$ http://www.transparency.org/whatwedo>.

${ }^{11}$ Louise I Shelley, "Transnational Organized Crime: The New Authoritarianism" in H Richard Friman \& Peter Andreas, eds, Illicit Glob Econ State Power (Lanham, Md: Rowman \& Littlefield Pub., 1999). 
underlying feature of ongoing drug wars in Mexico, the 2012 Arab Spring developments and continuing political instability in the Middle East, and international terrorism. For all these reasons, corruption in the global economy is an important concern of U.S. foreign policy and for international regulation.

\section{Transnational Bribery and the Origins of the FCPA}

While the bribery of domestic public officials has long been outlawed in the developed world, the payment of bribes across borders to foreign officials in the pursuit of international business has not. Until the late 1990s, official state support for bribery in international business was a standard practice in many OECD countries, roughly half of whom (including Australia, Austria, Belgium, France, Germany, Netherlands, Portugal, Norway, Sweden, and Switzerland) actively condoned and endorsed such payments by permitting them as tax-deductible business expenses. ${ }^{12}$ While other states did not render bribes tax-deductible, only a few of them explicitly prohibited the practice and only the United States, starting in 1977, prohibited such bribes as a criminal offense. Not only did several OECD states publicly defend and legitimate the practice of transnational bribery, Germany, France, and others also firmly opposed any multilateral effort to change this approach (George, Lacey, and Birmele 2000). Officials from these states argued that the bribery of public officials was a normal business practice in many countries-particularly less developed countries-and was therefore an acceptable practice for Western businesses engaged in commerce abroad (Brademas and Heimann 1998).

In contrast to this global context of legitimate, state-supported transnational bribery, the 1977 FCPA outlawed the bribery of foreign public officials in international business transactions through two sets of provisions. First, criminal law provisions under the jurisdiction of the Justice Department made it a criminal offense for any US person (individual or corporation) to make payments to foreign government officials to assist in retaining or obtaining business. Second, accounting and reporting provisions of the Act under the jurisdiction of the Securities and Exchange Commission (SEC) introduced record-keeping rules designed to expose such unlawful payments. Criminal penalties under the Act included fines of up to $\$ 2$ million dollars for firms, and up to $\$ 100,000$ and five years' imprisonment for individuals.

This unilateral constraint on US businesses arose as a result of Watergate-related revelations about foreign corrupt practices undertaken by major US corporations, the ethical

\footnotetext{
12 Milliet-Einbinder Martine 2000, "Writing Off Tax Deductibility. OECD Observer, May 26. <http://www.oecdobserver.org/news/fullstory.php/aid/245” (2001) 21 Print May.
} 
resonance of which led legislators to enact the FCPA, regardless of countervailing material strategic trade considerations and regardless of opposition by otherwise powerful business groups. Subsequent efforts to repeal or amend the FCPA were impeded by the post-Watergate significance of the deeply held norm of anti-corruption, which was explicitly articulated in the FCPA. 13

Thus from the outset, U.S. corporations and business groups strongly opposed this constraint on their ability to compete for business abroad against competitors in France, Germany, the UK, and elsewhere, who remained unconstrained from paying bribes to win contracts. Nevertheless, a decade of lobbying to repeal the Act's anti-bribery provisions failed to yield the results US businesses wanted: to be able to legally offer bribes for business in countries where, they argued, corrupt practices were the acceptable norm. Instead, in 1988 Congress amended the FCPA to clarify and strengthen (rather than repeal) its regulatory requirements and to require the President to seek to internationalize anti-bribery rules through negotiations at the OECD. ${ }^{14}$

\section{The FCPA in the 1990s: Policy Internationalization and the OECD Convention}

As a result, the United States became an international norm leader on anti-corruption and a crucial player in the emergence of a regime to govern corruption in the global economy. Specifically: a binding international treaty at the OECD to criminalize transnational bribery. Notwithstanding the powerful normative context of the FCPA, the motivation for US leadership on international anti-bribery rules at the OECD in the 1990s and beyond lay not in normative concerns, but in strategic trade calculations. Although the United States did not prefer a legallybinding treaty commitment to ban transnational bribery, it agreed to one at the behest of France and Germany, its partners in the OECD who wanted to be sure that if they were to repeal their own standard practices of permitting the tax-deductibility of foreign bribes, the United States would be constrained by a binding commitment (as opposed to a "merely" hortatory norm) to vigorously enforce its own anti-bribery measures. As a state-supported strategic trade practice, transnational bribery presents a prisoner's dilemma for states and firms competing for international business, and US-prompted negotiations for anti-bribery rules at the OECD, resulted in a binding multilateral Convention to curb it in the context of free-trade seeking neoliberal globalization. The 1997 OECD Convention on Combating Bribery of Foreign Public Officials in International Transactions, together with related recommendations, obligated its signatories to criminalize the bribery of foreign public

${ }^{13}$ Ellen Gutterman, "Easier Done Than Said: Transnational Bribery, Norm Resonance, and the Origins of the US Foreign Corrupt Practices Act" (2015) 11:1 Foreign Policy Anal 109.

${ }^{14}$ Ibid. 
officials on an extraterritorial basis, end the tax-deductibility of those bribes, and cooperate to monitor and enforce compliance. It became the legal centerpiece of a robust international regime of anti-corruption.

Today, the United States vigorously enforces the FCPA, the OECD Convention's signatories have all adopted similar kinds of legislation, and the Convention parties have conducted three rounds of rigorous peer-review monitoring to evaluate members' compliance and enforcement of the rules. According to the OECD, since 1997 over 300 individuals and companies have been sanctioned for foreign bribery under various national laws and hundreds more are under investigation. ${ }^{15}$ In addition, the 2005 United Nations Convention Against Corruption (UNCAC) has required its 140 signatories to outlaw a wide range of corrupt activities - including bribery of national and foreign public officials and officials of public international organizations; embezzlement and misuse of funds in both the public and private sector; laundering the proceeds of crime; obstruction of justice; and more - and has spawned the UNCAC Civil Society Coalition, which unites over 350 civil society organizations from over 100 countries in a global network aimed at promoting the ratification, implementation, and ongoing monitoring of the UNCAC and other anti-corruption initiatives. ${ }^{16}$ Most recently, the G20 group of states has formed a standing anti-corruption working group to promote private sector transparency and integrity, international cooperation on asset recovery regimes, and the prevention of corruption in the global extractive, fisheries, forestry, and construction industries. ${ }^{17}$ Beyond the FCPA, clearly, the global governance of bribery and corruption is growing.

\section{Enforcement of the FCPA in the $21^{\text {st }}$ Century: Data and Trends}

In the first twenty years of the FCPA's existence, from 1977-1997, the DOJ and SEC pursued a combined total of 44 enforcement actions against corporations and individuals found to have violated the FCPA's anti-bribery measures - an average of two per year. Nevertheless, U.S. companies complained bitterly about even this low measure of enforcement and pushed the government to "level the playing field" for U.S. business, either by repealing the bribery provisions

15 OECD, "OECD Working Group on Bribery Elects New Chair", (7 August 2013), online: OECD Better Policies Better Lives <http://www.oecd.org/daf/anti-bribery/oecd-working-group-onbribery-elects-new-chair.htm>.

16 United Nations Office on Drugs and Crime, "United Nations Convention Against Corruption", online: $<$ https://www.unodc.org/unodc/en/treaties/CAC/>; "UNCAC Coalition | Civil Society", online: $<$ http://uncaccoalition.org/en_US/>.

17 "First G20 Anti-Corruption Working Group Meeting held in Istanbul", online: G20 <https://g20.org/first-g20-anti-corruption-working-group-meeting-held-in-istanbul/> at 20. 
of the FCPA, or as a second choice, internationalizing the norms abroad. The government pursued the latter course of action and in 1997 concluded, with its partners, the OECD anti-bribery convention. From 1998 until 2003, the United States began to increase enforcement while the OECD partners focused on monitoring each other's implementation of the Convention's prohibitions into domestic law. Then, beginning in 2003 and over the next ten years, US enforcement of the FCPA dramatically increased. Data on FCPA enforcement over the past decade reveal two clear trends: A notable expansion of enforcement and a significant expansion of jurisdiction.

\section{Expansion of Enforcement}

In expanding their FCPA enforcement activities, the DOJ and the SEC have pursued more corporate enforcement actions, have extracted ever-increasing criminal fines, penalties, disgorgements of profit and other pecuniary damages, have pursued a greater number of actions against individuals, and have increasingly relied on deferred-prosecution and non-prosecution agreements to do so.

More corporate enforcement actions.

Since 2003 the DOJ and the SEC have concluded a combined total 166 FCPA enforcement actions - representing a five-fold increase over the previous 25-year period in the average annual rate of enforcement.

[Insert Table 1 - Bar graph showing corporate enforcement actions per year, 2002-2013]

[Insert Table 2 - Bar graph showing enforcement actions against individuals, 2002-2013]

\section{Huge fines.}

Perhaps more noteworthy than the number of enforcement actions is the increased value of criminal and civil fines, disgorgements of profits, and other penalties imposed in these actions. Total corporate fines over the past ten years have reached more than $\$ 5$ billion, with the average corporate penalty ranging from a low of five and a half million dollars (in 2005) to a high of $\$ 86$ million (in 2010). 2010 stands out as a particularly notable year for enforcement, including 21 corporate enforcement actions yielding approximately $\$ 1.8$ billion in fines and penalties. Even excluding 2010 as an anomaly, the average fine levied on corporations for FCPA violations from 
2004-2013 was approximately $\$ 39$ million. Several notable cases yielding fines greater than $\$ 100$ million have proved particularly headline-grabbing: Siemens (\$800 million) in 2008; Haliburton/KBR (\$579 million) in 2009; Technip (\$338 million) and BAE Systems ( $\$ 400$ million) in 201018; JGC Corp (\$218 million) in 2011; and Total S.A. (\$398 million) in 2013. It is also notable that five of these six cases involved non-U.S. entities.

\section{[Insert Table 3 - bar graph showing total corporate fines per year, 2003-2014]}

\section{[Insert Table 4 - showing average corporate penalties, 2003-2014]}

\section{Enforcement against individuals.}

In addition to an increased number of corporate enforcement actions, the DOJ has increased its enforcement of the FCPA specifically against individual defendants. From 2003-2013, 142 individuals were implicated in 59 FCPA enforcement actions and 45 individuals were criminally sentenced either to probation or to prison - far more than in any other jurisdiction enforcing rules against transnational bribery. FCPA prison sentences have varied widely, ranging from 9 months up to 15 years, with the average prison sentence just under three years. During the same period, individuals guilty of FCPA violations have also been charged over $\$ 180$ million in penalties. The average individual fine or penalty per enforcement action is $\$ 32$ million.

This level of individual enforcement had been meant as a clear signal to executives and employees at all levels that the US government intends to hold them - not just their firm -criminally responsible should they be found guilty of FCPA violations. Particularly under assistant attorney general Lanny Breuer, who headed the DOJ criminal division from 2009-2013 and led a concerted focus on the FCPA, enforcement against individuals was a cornerstone of the DOJ criminal enforcement activities. "No matter what", Breuer noted in 2012, referring to the FCPA, "individual executives and employees must answer for their conduct". ${ }^{19} 20$ According to DOJ reasoning, "to have a credible deterrent effect, people have to go to jail".21 22

18 Technically, BAE was not actually charged with an FCPA liability. Alongside a guilty plea to charges by the UK Serious Fraud Office (yielding what many observers considered to be a paltry fine of $£ 30 \mathrm{M}$ ), BAE pleaded guilty in the United States to violating both the US Arms Export Control Act and International Traffic in Arms regulations as well as to conspiring to defraud the United States by impairing and impeding its lawful functions and to make false statements about its Foreign Corrupt Practices Act compliance program. Nevertheless, this action is included in the Shearman and Sterling database of FCPA enforcement actions and is widely accepted as a FCPA enforcement action.

${ }^{19}$ One is also tempted to contrast Breuer's commitment to the deterrent value of the prosecution under the FCPA of (admittedly, primarily non-U.S.) executives with his consistent refusal to do so in connection with 
One reason to pursue cases against individuals is to prevent corporations from treating fines and penalties as a mere cost of doing business. In addition to the $\$ 800$ million fines and penalties collected in the Siemens case, for instance, eight executives went to jail. Another reason to pursue cases against individuals may be to secure cooperation in building larger cases against corporate entities or industries as a whole. This appears to have been at play in the case of Albert "Jack" Stanley, the former chief executive officer of KBR Inc - a spinoff of the Houston based oil services giant Halliburton - who in 2012 was sentenced to a 21/2 year prison term for his key role in a wide ranging bribery scheme in Nigeria. Stanley pled guilty in 2008 and his cooperation enabled the largest bribery prosecution to proceed at that time, involving multiple companies. According to his lawyer, Stanley proved to be "the linchpin, the foundation of the largest, most successful FCPA investigation ever." 23

In another case, in 2012, a former managing director in the Shanghai office of Morgan Stanley's real estate group was sentenced to nine months in prison for conspiring with a Chinese government official and a Canadian lawyer to misappropriate a multi-million dollar stake in a Shanghai apartment building being sold by a Morgan Stanley fund. From 2004-2007 Peterson had acquired millions in real estate investments for himself and the Chinese official, in exchange for business the official provided to Morgan Stanley's funds. 24

fraud in the financial crisis of 2008. In this connection, the criticism of Judge Jed Rakoff of the United States Court for the Southern District of New York is well-known: "But if, by contrast, the Great Recession was in material part the product of intentional fraud, the failure to prosecute those responsible must be judged one of the more egregious failures of the criminal justice system in many years." Jed S Rakoff, "The Financial Crisis: Why Have No High-Level Executives Been Prosecuted?", N Y Rev Books (9 January 2014), online: $<$ http://www.nybooks.com/articles/archives/2014/jan/09/financial-crisis-why-no-executiveprosecutions/>.

${ }^{20}$ Lanny A Breuer, Speech at the New York City Bar Association (New York, 2012).

${ }^{21}$ On the other hand Koehler The Foreign Corrupt Practices Act in a New Era (Edward Elgar Publishing, 2014). argues that that the emphasis on individual enforcement may be nothing so much as cheap talk and empty rhetoric, as the vast majority of FCPA enforcement actions are against corporations - possibly because these are the source of more lucrative fines and penalties, especially since the use of corporate DPAs and NPAs (discussed below) makes them easier to conclude.

${ }^{22}$ Cortney C Thomas, "Foreign Corrupt Practices Act: A Decade of Rapid Expansion Explained, Defended, and Justified" (2009) 29 Rev Litig 439.

${ }^{23}$ Laurel Brubaker Calkins, "Ex-KBR CEO Stanley Gets 2 1/2 Years in Prison for Foreign Bribes", (24 February 2012), online: Bloomberg <http://www.bloomberg.com/news/2012-02-23/ex-kbrceo-albert-stanley-gets-30-month-prison-term-in-nigeria-bribe-case.html>.

${ }^{24}$ Chad Bray, "Morgan Stanley Ex-Official in China Sentenced to 9 Months in Prison", Wall Str J (17 August 2012), online:

<http://online.wsj.com/articles/SB10000872396390444508504577593950506343444>; 
The longest sentence imposed on an individual for FCPA violations remains 15 years, given to Joel Esquanazi, the former president of a US-based telecommunications firm, who conspired to pay more than $\$ 890,000$ over several years to shell companies for the purpose of bribing Haitian government officials in exchange for various business advantages, including preferred telecommunications rates and continued telecommunications connections with Haiti. Esquanazi's co-defendant received a seven-year sentence; both sentences were upheld on appeal in 2014. At the time the Department of Justice noted the sentence would be "a stark reminder to executives that bribing government officials to secure business advantages is a serious crime with serious consequences [...] we will continue to hold accountable individuals and companies who engage in such corruption." 25

\section{Diversion Agreements.}

In addition to the increased number of enforcement actions against individuals and corporations, a particular hallmark of recent FCPA enforcement is the prevalence of deferredprosecution agreements (DPAs) and non-prosecution agreements (NPAs)—known as "diversion agreements"-in FCPA enforcement. ${ }^{26}$ These means of escaping prosecution permit corporations implicated in FCPA violations to avoid criminal prosecution in exchange for admission of wrongdoing and various other stipulations related to reform such as undertaking comprehensive compliance systems, hiring compliance advisors, paying significant financial penalties, and restitution. Diversion agreements have become an essential component of FCPA enforcement: since 2008 not a single corporate criminal action for FCPA violations has been concluded without a DPA or NPA in place. ${ }^{27}$

As Thomas ${ }^{28}$ recounts, DOJ initially conceived of pretrial diversion of corporate criminal cases as a potential reward prosecutors could bestow upon corporations in exchange for cooperation in FCPA investigations. They were also seen as a useful tool for instigating changes in corporate culture in favour of more rigorous FCPA compliance. In addition, in the wake of the 2001-2002

Christopher M Matthews, "Former Morgan Stanley Exec Gets Nine Months in FCPA Case", Wall Str J (17 August 2012), online: <http://blogs.wsj.com/corruption-currents/2012/08/17/formermorgan-stanley-exec-gets-nine-months-in-fcpa-case/>.

25 Office of Public Affairs, Executive Sentenced to 15 Years in Prison for Scheme to Bribe Officials at State-Owned Telecommunications Company in Haiti (US Department of Justice, 2011).

${ }^{26}$ Severin Wirz, Private Settlements, Public Concerns: Judicial Scrutiny of Deferred Prosecution Agreements (TRACE International, 2013).

27 Note that diversion agreements protect the corporate defendant from criminal penalties, while | individual miscreants may still receive criminal convictions and jail terms.

28 supra note 22 . 
Arthur Anderson scandal, in which the firm itself went bankrupt and thousands of people lost their jobs due to the malfeasance of a relatively small unit of the company, DOJ views DPAs and NPAs as a sort of corporate harm-reduction strategy in an era of heightened enforcement. Not least, it also seems this new approach to prosecution has been a boon for the extraction of ever-greater financial penalties.

In addition to securing cooperation, influencing corporate culture, mitigating systemic risk to defendants and generating lucrative fines, prosecution diversion agreements avoid lengthy investigations, costly evidence gathering and expensive trials. By the same token, however, as critics have noted, enforcement via DPA and NPA has facilitated the extra-judicial enforcement authority of the DOJ and the SEC, in which the absence of trial judgments precludes the development of case law which might limit the reach of FCPA enforcement and on which FCPA defenses might otherwise be based ${ }^{29}$.

\section{Will the trend of expanded enforcement continue?}

Another notable aspect of increased enforcement serves somewhat as a caveat: the data reveal sharp spikes in enforcement as a function of one or two record-breaking cases. Specifically, the UN Oil-for-Food scandal and the wide-ranging Siemens bribery scandal alone are responsible for enforcement spikes in the period 2008-2010. As cases resulting from these massive investigations resolve, it is possible that these years will remain outliers and the trend of increased enforcement will recede. On the other hand, given that a number of companies continue to disclose investigations and the pipeline of cases the DOJ and SEC intend to resolve continues to grow, this trend is more likely to continue. In addition, the FCPA Unit of the SEC's enforcement division has markedly increased its scrutiny on compliance, through a heightened focus on assessing the sufficiency of companies' efforts to comply with the SEC's anti-bribery and books and records measures. The SEC has emphasized that corporate FCPA compliance programs must be integrated into companies' overall systems of compliance controls. In other words, companies must have in place customized compliance programs that address bribery and reporting risks specific to each individual company's business; "one size fits all" or "off the shelf" compliance programs are not deemed sufficient ${ }^{30}$. In the present regulatory environment in which the Sarbanes-0xley and Dodd-Frank Acts already present a heightened focus on corporate governance, financial reporting

${ }^{29}$ Mike Koehler, "FCPA 101", online: FCPA Profr <http://www.fcpaprofessor.com/fcpa-101>.

30 Randall J Fons, Brian Neil Hoffman \& Tiffany A Rowe, The SEC Speaks: Reflections and Enforcement Initiatives in 2013 (Morrison Foerster, 2013). 
and oversight, and corporate compliance, FCPA scrutiny and compliance are likely to continue to yield significant enforcement actions in the coming years. ${ }^{31}$.

\section{Expansion of Jurisdiction}

In addition to expanded enforcement efforts through various actions, including investigations, DPAs, NPAs, and individual prosecutions, a hallmark of FCPA enforcement in the past ten years has also been an increase in enforcement against foreign issuers and nationals and a notable expansion of the basis upon which the DOJ asserts jurisdiction in FCPA enforcement. Since its introduction in 1977, the FCPA has always included elements of extra-territoriality, in that it applied to actions occurring outside the territory of the United States. However, the original statute applied only to domestic concerns and U.S. citizens and it included elements that required a territorial "nexus" to the United States for the jurisdiction of the American courts and law enforcement to apply to acts of bribery abroad. Then, the 1998 amendments to the Act expanded its jurisdiction over non-US entities. Though still requiring some territorial nexus, for the first time the 1998 amendments introduced non-U.S. issuers as subjects of the law. In addition, as it has been applied over the past decade, the definition of what constitutes a territorial "nexus" has been stretched to include ever more broad extra-territorial reach.

\section{Enforcement Against Foreign Issuers and Nationals}

In recent years both the DOJ and SEC have increased enforcement actions against foreign entities and individuals. Since 2003, more than a third of enforcement actions against individuals have been against foreign (non-U.S. citizen) defendants. In some years, the rate of enforcement against foreign defendants has been much higher; in 2011, for instance, $85 \%$ of individual defendants in FCPA cases were non-U.S. nationals. As for corporate enforcement actions, $40 \%$ since 2003 have been against foreign issuers; in particular, some of the most notable actions yielding the greatest fines have been against foreign issuers rather than domestic concerns.

The first time the Department of Justice took criminal enforcement action against a foreign issuer for violating the FCPA was in the Statoil case, which the department resolved in 2006. This case involved illicit payments (totaling $\$ 15.2$ million over 11 years) by a Norwegian oil and gas company to an Iranian Oil Ministry official, in exchange for oil and gas contracts. To resolve the matter, the Norwegian firm agreed to a $\$ 10.5$ million criminal penalty and entered into a 3-year

${ }^{31}$ Heidi L Hansberry, "In Spite of Its Good Intentions, the Dodd-Frank Act Has Created an FCPA Monster" (2012) 102:1 J Crim Law Criminol 195. 
DPA. The DPA included a requirement that Statoil hire an FCPA consultant in addition to other reforms. At the time, the DOJ intended this case "to send a clear message today that if a foreign company trades on U.S. exchanges and benefits from U.S. capital markets, it is subject to our laws. The Department will not hesitate to enforce the FCPA against foreign-owned companies, just as it does against American companies". 32

In the past decade, $37 \%$ of all foreign bribery actions and investigations by the US have involved a company headquartered outside the United States or an individual employed or retained by such a company. Key examples of extraterritorial enforcement of the FCPA include cases against the Swiss firm Panalpina, Germany's Siemens, and the UK's BAE Systems, all of which concern nonUS companies headquartered outside the United States engaging in behaviour outside the United States proscribed by the FCPA (and also prohibited by the OECD Convention.) ${ }^{33}$

\section{Increasingly Expansive Interpretation of the FCPA's Jurisdictional Reach.}

Not only has enforcement of foreign issuers and foreign nationals increased, the DOJ and the SEC have also significantly expanded the basis upon which they argue for the required "nexus" between the foreign entity or individual and the United States. ${ }^{34}$ A 2011 case concerning the engineering, procurement, and construction contracts to design and build a liquefied natural gas plant and related constructions on Bonny Island, Nigeria particularly illustrates the widening jurisdictional application of the FCPA. The defendant in this case, JGC Corporation, was the first Japanese company prosecuted under the FCPA and is neither a domestic U.S. concern nor an issuer of securities in the U.S. capital markets or on its exchanges. Jurisdiction was based on JGC's role in "conspiring to execute the bribery scheme with co-conspirators who are domestic concerns or issuers, and causing allegedly corrupt U.S. dollar payments to be wire transferred via correspondent bank accounts in New York". 35

In 2012 the DOJ and the SEC issued a 120-page guidance document (the "2012 Guide") to clarify for compliance purposes the FCPA's rules concerning personal jurisdiction. While confirming that issuers and domestic concerns are subject to the FCPA by virtue of nationality, and foreign entities may be subject by way of the territoriality principle for acts committed in the United States in furtherance of a violation, the 2012 Guide further asserts that FCPA jurisdiction over "a foreign

\footnotetext{
${ }^{32}$ Alice S Fisher, Prepared Remarks for the American Bar Association National Institute on the Foreign Corrupt Practices Act, Washington DC (US Department of Justice, 2006).

33 See note 15.

${ }^{34}$ Natasha N Wilson, "Pushing the limits of jurisdiction over foreign actors under the Foreign Corrupt Practices Act” (2014) 91:4 Wash Univ Law Rev 1063+.

35 Urofsky, supra note 4 at 46.
} 
national or company [that] aids and abets, conspires with, or acts as an agent of an issuer or domestic concern, regardless of whether the foreign national or company itself takes any action in the United States." 36. This interpretation may exceed what the language of the statute actually allows. 37

Most recently, in 2013 the French firm Total SA paid the third largest settlement in FCPA history ( $\$ 398$ million) in a case with only the most tenuous of jurisdictional connections. The case involved improper conduct alleged to have occurred between 1995 and 1997, during which time the French oil and gas company allegedly bribed an Iranian official through use of an employee of a Swiss private bank and a British Virgin Islands company. The sole U.S. territorial nexus (the required legal element for an anti-bribery violation, since Total is a foreign issuer) was a 1995 wire transfer of $\$ 500,000$ (representing less than $1 \%$ of the alleged bribe payments at issue) from a New York based account. 38

\section{Recent Court Cases.}

Two recent cases illustrate the extent to which jurisdiction remains one of the FCPA's most questionable statutory issues. In February 2013, Judge Richard J. Sullivan of the U.S. District Court for the Southern District of New York denied a motion to dismiss for lack of jurisdiction the case of SEC vs. Elek Straub, Andras Balogh, and Tamas Morvai - three Hungarian former executives of Hungarian firm Magyar Telekom (majority-owned by Germany's Deutsche Telekom AG) - charged with orchestrating a scheme to bribe public officials in Macedonia and of providing false and misleading financial representations to auditors and to the SEC. The defendants' actions had triggered the personal jurisdiction of the court, Sullivan decided, because they were "engaged in conduct that was designed to violate the United States securities regulations" and therefore directed toward the United States. In addition, the defendant's use of email messages in furtherance of the bribery scheme "from locations outside the United States [and to recipients also outside the United States] but routed through and/or stored on network servers located within the United States" was sufficient to trigger territorial jurisdiction -- whether or not the defendants had the

\footnotetext{
${ }^{36}$ Criminal Division US DOJ \& Enforcement Division US SEC, FCPA: A resource Guide to the U.S. Foreign Corrupt Practices Act (2012) at 16.

37 Bruce J Casino \& Scott Maberry, "FCPA, Due Process, and Jurisdictional Overreach by the DOJ and SEC" (2013) 13:3 Crim Litig 5.

38 Mike Koehler, “Total Agrees To Pay \$398 Million To Resolve Its FCPA Scrutiny", (30 May 2013), online: FCPA Profr <http://www.fcpaprofessor.com/total-agrees-to-pay-398-million-toresolve-its-fcpa-scrutiny>; Mike Koehler, “Total'ly Milking The FCPA Cash Cow?", (3 June 2013), online: FCPA Profr <http://www.fcpaprofessor.com/totally-milking-the-fcpa-cash-cow>.
} 
intention of using any U.S. means or instrumentalities of interstate commerce in furtherance of their bribery scheme.

In the same month, Judge Shira Sheindlin, also of the U.S. District Court for the Southern District of New York, granted a motion to dismiss charges against Herbert Steffen, the former chief executive officer of Siemens S.A. Argentina, the Argentine subsidiary of Germany's Siemens AG, in a case in which the SEC had charged seven former executives of Siemens with a decade-long program of bribing public officials in Argentina to obtain a $\$ 1$ billion contract to produce national identity cards for Argentine citizens. In this case, Judge Sheindlin agreed with the defendant's submission that Steffen, a German national, had virtually no contact with the United States (and his actions were not directed against the United States) and therefore the court lacked personal jurisdiction over him.

Despite the different outcomes, both judges applied similar analyses in these cases to decide on the jurisdiction of the U.S. District Court over foreign corporate bribery schemes by foreign nationals. The contrasting outcomes result from important differences in the facts of each case, not from conflicting points of law. The Sullivan decision, in particular, appears to support current DOJ and SEC theories of jurisdiction, which assert that minor or pass-through acts, such as wire transfers or emails through American correspondent bank accounts, are sufficient to establish jurisdiction, even if the money or correspondence is not knowingly or intentionally routed to the United States and do not remain in the United States for a significant length of time. 39

Moreover, although the Sheindlin decision does set limits on the personal jurisdiction of the court over non-U.S. actors, the government clearly has established - through the 2012 Guide and elsewhere - that it intends to assert jurisdiction over foreign defendants accused of bribery, aiding and abetting bribery, or conspiracy to bribe, even when the defendants themselves may not be directly implicated in acts of bribery per se. ${ }^{40}$.

Perhaps most importantly, the Sullivan and Sheindlin decisions stand as clear exceptions to the trend in FCPA enforcement of diversion agreements. As stated above, nearly all of the criminal corporate resolutions of the past ten years have been in the form of deferred or non-prosecution agreements, while resolutions of corporate civil cases brought by the SEC mainly have consisted of administrative cease-and-desists orders and civil settlements. While for businesses, the practical consequence of these resolutions are allegations of wrongdoing, admissions of guilt in criminal

${ }^{39}$ Lauren Ann Ross, "Using foreign relations law to limit extraterritorial application of the Foreign Corrupt Practices Act", Duke Law J (November 2012) 445+.

40 Urofsky, supra note 4 at xiii. 
cases, penalties, monitoring or reporting, limits of public statements, and bad publicity ${ }^{41}$, for the legal environment in which businesses operate, the main consequence is that DPAs and NPAs, generally, have been exempt from judicial scrutiny. ${ }^{42}$ It may be that in "overreaching" on jurisdiction the government expects that companies will choose to settle with diversion agreements rather than to test the limits of the government's jurisdiction in court. ${ }^{43}$ Thus it stands that while in recent cases such as Morrison v. Australia National Bank, Ltd. In 2009 and Kiobel v. Royal Dutch Shell Co. in 2013 U.S. courts up to and including the Supreme Court have been limiting the extraterritorial application of U.S. law ${ }^{44}$, the area of FCPA enforcement remains one of expanding extraterritoriality in which the United States anti-corruption law reaches farther and farther into global regulatory environments and into other sovereign jurisdictions.

\section{Discussion and Implications}

Why do the expansion of FCPA enforcement and extraterritoriality in FCPA enforcement matter? What are the implications of these developments?

In the first place, as leading FCPA observers have noted, this obviously means that any issuer with registered U.S. securities and their employees - whether U.S. or non U.S. persons - should be increasingly wary of running afoul of the FCPA in this "new era" of enforcement 45 . In fact, as enforcement has increased and the risks of prosecution for bribing abroad have grown, an entire industry of FCPA compliance experts, consultants, trainers, lawyers, investigators, and researchers has arisen to meet the concerns of business in the new regulatory environment. If one is interested in following day-to-day developments in FCPA enforcement in this compliance industry, one can follow any number of online publications such as the widely-read FCPA blog, FCPA Professor, and Compliance Week; subscribe to services like those of TRACE International; and contract the services of such FCPA compliance firms as Risk Advisory, Mintz Group, FTI Comply, Alix Partners, (not to mention a host of U.S. and foreign law firms and consulting firms) and many others - which

41 Urofsky, supra note 4.

${ }^{42} \mathrm{~A}$ recent decision has held that the court, pursuant to its "supervisory power", has authority to approve and oversee the implementation of DPAs, though not NPAs, which fall into the government's "absolute discretion to decide not to prosecute". This may influence the DOJ's decision to pursue NPAs as opposed to DPAs in future enforcement actions. U.S. v. HSBC Bank USA (in a non-FCPA case), Judge John Gleeson of the Eastern District of New York.

${ }^{43}$ Casino \& Maberry, supra note 37.

${ }^{44}$ Paul Stephan, "The Political Economy of Extraterritoriality" (2013) 1:1 Polit Gov 92; Claire Bright, The Implications of the Kiobel v. Royal Dutch Petroleum Case for the Exercise of Extraterritorial Jurisdiction, SSRN Scholarly Paper ID 2364707 (Rochester, NY: Social Science Research Network, 2013).

${ }^{45}$ Koehler, supra note 21. 
advertise on the various online FCPA blogs and publications. FCPA compliance is big business, and lawyers, accountants and consultants have been making fortunes helping companies to navigate the new FCPA enforcement environment ${ }^{46}$.

At the same time recent patterns of FCPA enforcement hold deeper implications for the global governance of corruption, in at least two ways: US enforcement of the FCPA promotes anti-bribery and anti-corruption policies and enforcement abroad, leading to the development of an ever-more robust framework of anti-corruption governance at the global level; it also shapes and constrains the direction and manner of global anti-corruption governance, in both intentional and unintentional ways.

\section{Anti-Corruption Promotion}

On the one hand, U.S. enforcement of the FCPA can be read as a laudable effort by the United States to contribute to the global prohibition regime against transnational bribery and corruption, particularly that associated with the OECD anti-bribery convention. Political science research, for instance, has shown a powerful association between extraterritorial FCPA enforcement actions by U.S. prosecutors and the national enforcement of foreign bribery regulations in target countries. Kaczmarek and Newman 47 found that jurisdictions that experienced U.S. intervention were twenty times more likely to enforce their own national anti-corruption rules than jurisdictions which received no FCPA attention. In this sense, the FCPA stands as a key tool of the global anticorruption regime, in which the United States is the leading enforcer. To the extent that transnational bribery distorts markets, disrupts international flows of goods and capital, reduces economic growth, impedes fair market competition, obstructs liberal international trade, impedes sustainable development and perpetuates poverty, this enforcement promotes positive outcomes and mutual benefits in global politics. As Rose-Ackerman puts it, "there is a need for U.S. leadership in this area of global concern". 48

Shaping - and Constraining - International Anti-Corruption Efforts

\footnotetext{
${ }^{46}$ Nathan Vardi, "The Bribery Racket", Forbes (7 June 2010), online: $<$ http://www.forbes.com/global/2010/0607/companies-payoffs-washington-extortionmendelsohn-bribery-racket.html>.

47 "The Long Arm of the Law: Extraterritoriality and the National Implementation of Foreign Bribery Legislation" (2011) 65:4 Int Organ 745.

${ }^{48}$ Susan Rose-Ackerman, "International anti-Corruption Policies and the U.S. National Interest" (2013) 107 Am Soc Int Law Proc 254 at 255.
} 
Shaping - and Constraining - International Anti-Corruption Efforts

At the same time, however, the extra-territorial application of the FCPA to ban bribery abroad raises important questions concerning the roles of power, legitimacy, justice, cooperation, efficacy, and national interest in global governance. As such it requires further scrutiny as to the impact of this legislation on the scope and direction of global anti-corruption efforts. Three aspects of FCPA enforcement in particular serve to constrain the broader goals of global anti-corruption efforts: The narrow conception of corruption upon which the FCPA is based, the strategic trade frame which underlies the FCPA's internationalization, and the legitimacy problems these suggest.

\section{Narrow conception of corruption}

Given its stringent enforcement of the FCPA, the United States stands today as the most significant promoter and enforcer of anti-corruption norms in the global economy. To the extent that U.S. leadership in the global governance of corruption is activated by FCPA enforcement, however, it fulfils this role on the basis of the specific conception of corruption included in the FCPA: transactional bribery. Specifically, the FCPA prohibits any offer, payment, promise to pay, or authorization of the payment of money or anything of value to any person "while knowing that all or a portion of such money or thing of value will be offered, given or promised, directly or indirectly, to a foreign official to influence the foreign official in his or her official capacity, induce the foreign official to do or omit to do an act in violation of his or her lawful duty, or to secure any improper advantage in order to assist in obtaining or retaining business for or with, or directing business to, any person." 49 Transactional bribery of this sort is well-illustrated in Principal-Agent (PA) theory-based models of corruption. ${ }^{50}$ Derived from economic theory, the PA approach models corruption as an incentive-driven individual choice within an institutional context in which institutional failure leads to a breakdown (corruption) in the optimal allocation of resources and outcomes. Put differently, in the PA model agents are presumed to act on behalf of principals that have delegated authority to them and are empowered to monitor and enforce the extent to which agents carry out the principal's interests. Corruption enters the picture when a third party whose gains or losses depend on the principal or the agent interferes with the appropriate principal-agent

49 US Department of Justice, "Foreign Corrupt Practices Act", online: <http://www.justice.gov/criminalfraud/foreign-corrupt-practices-act>.

50 Nico Groenendijk, "A principal-agent model of corruption" (1997) 27:3-4 Crime Law Soc Change 207; Susan Rose-Ackerman, Corruption and government: causes, consequences, and reform (Cambridge: Cambridge University Press, 1999); Alberto Vannucci \& Donatella della Porta, Corrupt Exchanges: Actors, Resources, and Mechanisms of Political Corruption (New York: Aldine Transaction, 1999). 
relationship. In the P-A model, corruption is defined as any unauthorized transaction between an agent and a third party - usually bribery - and is an instance of institutional failure. 51

While transactional bribery certainly is the most basic and universally recognized manifestation of corruption around the world, it is only one aspect of the complex patterns and myriad forms of corruption which affect the daily lives of ordinary people.52 Broader, network-based patterns of corruption, for example, such as kleptocratic regime practices - including outright theft from the public treasury by governing elites; the infiltration of official bodies by organized crime; electionrigging; illicit political campaign finance; and various other forms of police, judicial, and political corruption - are not necessarily structured as the kind of explicit quid-pro-quo transaction which is often assumed to be the hallmark of a corrupt relationship. In contrast to the focus on individual decision-making and institutional failure in the principal-agent based model of corruption, network-based models of corruption illuminate the non-transactional social aspects of corruption. They focus on how informal institutions, such as culture, religion, social norms, and various kinds of personal networks can shape systemic corruption in a society . More specifically, they reveal the manner in which informal and exclusive networks based on mutual trust and reciprocity - rather than an explicit quid pro quo - conceal illicit activity within legitimate organizations and networks, and how corruption can flourish even in advanced democracies - not just in developing societies with presumably weaker bureaucratic institutions prone to bribery.

For example, in the Elf-Aquitaine scandal in France in the 1990s, elite social and political networks linked members of the French political class, created patterns of both formal and informal relationships, and permitted both legitimate and illegitimate pursuits within established institutions. In particular, a policy network of graduates of the elite French postgraduate schools including the prestigious École National D' Administration (ENA) overlapped with elite business and social networks. Illicit networks of associates across these spheres easily became nested within legitimate associations, enabling corruption in France to occur on a grand scale - not always connected to explicit transactional bribery. ${ }^{53}$

In other contexts social networks based on primary interpersonal relationships such as family, kinship, and ethnicity can slant officials' exchanges and communications and shape their norms to favour close relatives and other groups or individuals over the interests of the general public, as in patrimonial and neo-patrimonial politics in countries like Afghanistan and in many African and

\footnotetext{
51 Rose-Ackerman, supra note 50; Vannucci \& Porta, supra note 50; Groenendijk, supra note 50.

52 The seminal contribution on bribery remains John Thomas Noonan, Bribes (Macmillan, 1984).

53 John R Heilbrunn, “Oil and Water? Elite Politicians and Corruption in France” (2005) 37:3 Comp Polit 277.
} 
Asian states. ${ }^{44}$ Social networks based on secondary relations such as professional and religious ties can also produce non-transactional corruption in countries with more advanced bureaucracies. Guanxi networks in China, for example, indicate the presence of direct, particularistic ties between individuals or organizations, which draw on underlying moral principles derived from the Confucian heritage - including hierarchy, interdependence, and reciprocity - to fill in governance gaps during periods of uncertain transition, relative disorder, and social inequality. ${ }^{55}$ Guanxi and social networks like it often override the norms and desired outcomes of formal institutions and produce corruption without necessarily including specific bribery transactions.

Furthermore, scholarly studies of criminal networks reveal how these often substitute bribery with violence, coercion and terrorist-like activities to extract gains and exert influence in and from political institutions. ${ }^{56}$ Criminal behaviour and coercive methods - which have been especially important sources of corruption in the transition and post-transition Eastern European countries as well as in several African and Latin American countries, and do not necessarily entail the explicit bribery of public officials in the context of business operations - can have deep impacts on democratic institutions. The effects of criminal-network-based corruption can reach to the extent of systematically modifying the rules of public policy to favour illicit activity and personal gain, from within a regime. In some cases, criminal organizations fully supplant the institutions of the state; in such cases identifiable instances of transactional bribery are merely the tip of the iceberg. ${ }^{57}$

For all its vigor and surrounding rhetoric about stamping out corruption in international business, however, US enforcement of the FCPA challenges none of these corruption-network practices. Rather, it funnels 'anti-corruption' resources and attention to a narrow focus on transactional bribery in international business, in a manner that resembles the "stovepiping" which has been identified as a problem in the global governance of health.58 "Stovepiping" in global health policy refers to a pattern in which resources are funneled down a narrow channel - say to a specific focus on HIV/Aids transmission rather than maternal health more generally - at the expense of broader goals. As Laurie Garrett has put it, stovepiping tends to reflect the interests of aid donors,

\footnotetext{
54 Ron Holt, "Beyond the Tribe: Patron-Client Relations, Neopatrimonialism in Afghanistan" (2012) 38:1 Mil Intell Prof Bull 27; Mushtaq H Khan, "Patron-Client networks and the economic effects of corruption in Asia" (1998) 10:1 Eur J Dev Res 15.

55 Jing Zhan, "Filling the gap of formal institutions: the effects of Guanxi network on corruption in reform-era China" (2012) 58:2 Crime Law Soc Change 93.

56 Luis Garay-Salamanca, “Institutional impact of criminal networks in Colombia and Mexico" (2012) 57:2 Crime Law Soc Change 177; Louise I Shelley, "The Unholy Trinity: Transnational Crime, Corruption, and Terrorism" (2005) 11:2 Brown J World Aff 101.

57 Shelley, supra note 11.

58 Laurie Garrett, "The Challenge of Global Health", Foreign Aff (2007) 14.
} 
not its recipients. ${ }^{59}$ Put in terms of the global regime of anti-corruption, US enforcement of the FCPA reflects US interests and not those of the millions of people around the world who are in desperate need of credible and effective strategies to curb the most damaging manifestations of corruption. The stovepiping of anti-corruption enforcement through the FCPA's narrow focus on bribery in international business should yield to a broader understanding of anti-corruption enforcement and a far more generalized approach to curbing corruption in its many forms, within the context of the global anti-corruption regime.

In sum, corruption is not always as obvious as the payment of money in exchange for services rendered, the perversion of agency relationships by third parties, or "the abuse of entrusted power for private gain."60 It can be much more subtle (and also deeply societally-entrenched), having to do with longstanding relationships of mutual benefit, exchanges of favours among people in advantageous positions, and expectations of reciprocity within ongoing relationships maintained by exclusive networks of trust, both licit and illicit. In such cases, anti-corruption policies which do not take into account the informal institutions of society that may sustain 'corruption' - culture, religion, ethnic norms, or various types of social network - are doomed to fail. And yet the FCPA comprises a narrow conception of corruption which focuses exclusively on transactional bribery. Also ignored in the statute -- and, consequently, in the global regime -- are the broader patterns of transnational corruption networks and the global practices in which bribery transactions are embedded, which often do not involve an individual business transaction but in which US actors often are complicit. The FCPA's focus on discrete incidents of bribery tends to single out specific actors for corrupt deeds and specific instances of corrupt transactions rather than tackling the embedded networks and practices in which opportunities for corruption are cultivated both locally and in the global economy writ large. Such corruption entails multiple sets of connected transactions, processes and relationships that unfold within a variety of transnational networks both licit and illicit - and they are rarely isolated instances that occur exclusively within countries. ${ }^{61}$

\section{The strategic trade frame}

The efficacy of US anti-corruption policy has been constrained by the FCPA's narrow focus on bribery transactions. It has also suffered from an enforcement strategy driven primarily by

\footnotetext{
59 Ibid.

${ }^{60}$ Transparency International, "What is Corruption?", online: Transpar Int - Glob Coalit Corrupt $<$ https://www.transparency.org/what-is-corruption>.

${ }^{61}$ Alexander Cooley \& Jason Sharman, The Price of Access: Transnational Corruption Networks in Central Asia and Beyond (San Francisco, CA, 2013).
} 
strategic trade concerns rather than anti-corruption concerns. Theories of strategic trade explain the conditions under which states will intervene in trading markets at the industry or firm level, in order to improve the competitiveness and maximize the benefits accruing to the state, the industry, or the firm.62 Taking a view of trade as competitive rather than as a source of mutual gain, strategic trade policies are used in order to raise one state's income at the expense of that of a competing state. ${ }^{63}$ Historically, export promotion policy in particular has been used by states in the pursuit of national power. ${ }^{64}$ For decades leading up to the emergence of the global regime of anti-corruption in the 1990s, state support for transnational bribery -- as in its tax-deductibility, financial support through export credit arrangements, or the public characterization of bribery as a normal business practice - functioned as a crucial prong in the toolkit of export promotion and strategic trade among major trading states. 65

Viewed through this lens, the international regime of anti-corruption can be seen as an attempt by the United States to internationalize specifically American norms concerning the conduct of international business, which first took shape in the FCPA. For twenty-odd years following the enactment of the FCPA in 1977, US trade and business interests saw themselves at a disadvantage in the global market for certain types of bribery-prone transactions, notably arms and defenserelated technology; infrastructure design and construction; and big-ticket sales of goods in the aerospace, telecommunications, energy and construction sectors. 66 In the strategic trade frame, then, US enforcement of the FCPA is a response to other states and their firms' longstanding and routine recourse to bribery in competitive export markets. The key point is that the central purpose of US enforcement of the FCPA is to ensure competitive access to global markets by U.S. firms - and not to control corruption more generally. It is an attempt to internationalize and enforce U.S. policy in the global regulatory environment in order to shape the international business environment to the advantage of U.S. enterprises. It is an effort to "level the playing field" for US based multinationals by enforcing a standard set of global regulatory rules, rather than a credible or efficacious policy of anti-corruption.

62 Marc L Busch, Trade Warriors: States, Firms, and Strategic Trade Policy in High-Technology Competition (Cambridge: Cambridge University Press, 1999); Paul R Krugman \& Alistair Smith, eds, Empirical Studies of Strategic Trade Policy (Chicago and London: University of Chicago Press, 1994).

${ }^{63}$ For instance, states can intervene by subsidizing favoured firms or industries at the input level (as with research and development [R\&D] subsidies), at the output level (as with export-promotion subsidies), or by protecting firms and industries from foreign competition through tariff or non-tariff trade barriers.

${ }^{64}$ GPE Walzenbach, Co-ordination in Context: Institutional Choices to Promote Exports (Aldershot, UK: Ashgate, 1998).

652000 , supra note 12.

66 Transparency International, “Bribe Payers Index: Overview”, (2013), online: Transpar Int - Glob Coalit Corrupt <http://www.transparency.org/research/bpi/overview>. 
A skeptical view of US anti-corruption enforcement policy might then ask two questions: Is the focus on bribery transactions intended to insulate from prosecution the offending organizations and their leadership, by focusing on the individual bribery transaction rather than the organizational pattern of behavior? And, does the focus on individual bribery transactions undermine the effectiveness of the penalties imposed for offensive activities? Sanctions and fines imposed without further disruption to a company's operations - amounting to only a fraction of the revenue generated by corrupt transactions - may be internalized by firms as a mere cost of doing business. Indeed, the US government has not been eager to debar companies found guilty of FCPA violations from further business dealings with the U.S. government or from eligibility for U.S. government contracts.

\section{Legitimacy}

The strategic trade analysis of transnational bribery raises a third point about the way in which US enforcement of the FCPA shapes and constrains not just the efficacy of the global regime of anticorruption, but its legitimacy as well. Questions of legitimacy raise complicated questions about power, democracy, ethics, and justice that are often glossed over in global governance, as the most powerful states - and the non-state actors of which powerful states approve - tend to be the ones to set the agenda and shape the rules for international action. As scholars of global governance are increasingly concerned with identifying the sources of political legitimacy beyond the state, research on legitimacy asks such questions as: What are the normative, sociological, and political bases of "legitimate" global governance? Which actors should exercise power at the global level, and what rules should guide their action? How might the effectiveness of crucial "transplanetary regimes" for governing finance, migration, disease control, disarmament, and ecological integrity be improved by increasing their legitimate bases of authority beyond the state? What are the "legitimacy criteria" for evaluating the institutional processes of global governance? More critically, what are the various processes of legitimization at work in global governance? These are deep, complicated, and important questions, and legitimacy remains a central concern in ongoing debates about reforming global governance for greater effectiveness, accountability, and justice.67

\footnotetext{
67 James Brassett \& Eleni Tsingou, "The Politics of Legitimate Global Governance" (2011) 18:1 Rev Int Polit Econ 1; Steven Bernstein, "Legitimacy in intergovernmental and non-state global governance" (2011) 18:1 Rev Int Polit Econ 17; Ellen Gutterman, "The Legitimacy of Transnational NGOs: Lessons from the Experience of Transparency International in Germany and France" (2014) 40 Rev Int Stud 391.
} 
With respect to the global governance of anti-corruption, recent patterns of US enforcement in the regime raise two sets of legitimacy concerns. First, are the norms, rules, and principles of international anti-corruption right, correct, and appropriate? Are the makers of these rules right and appropriate in doing so? Is it appropriate to rely on private governance and firm-led compliance promises to deliver results and expectations concerning the control of corruption? Other authors have noted that the use of corruption indicators such as the country-ranking system of Transparency International, functions as a technology of governance and power68. Similarly, US enforcement of the FCPA in the global regulatory environment can be read as an exercise of sheer hegemonic power. Rather than automatically applauding FPCA enforcement as a boon for global anti-corruption efforts, then, scholars and practitioners should probe more deeply into the normative implications of US leadership in this area - driven as it has been by US strategic interests and particularly American norms of international business regulation.

A second set of legitimacy concerns arises out of the impact of FCPA enforcement on the centralization of global regulation, which international law scholar Benedict Kingsbury and others suggest may be contrary to fairness and global justice.69 There is a powerful trend toward centralization in international business regulation and international law generally, which invites an examination of global enforcement regimes. In the emerging area of Global Administrative Law, for example, scholars are noting how increasingly developed, overlapping sets of diverse mechanisms of global regulation have become important to the strengthening - or erosion - of legitimacy and effectiveness in a range of governance regimes. Global Administrative Law has become a focus for examining the extent to which global regulatory regimes meet sufficient standards of transparency, consultation, participation, rationality, and legality and provide effective review of global rules and decisions. ${ }^{70}$ A similar analysis of the global anti-corruption regime is needed. To the extent that the global regime of anti-corruption is today almost completely driven by unilateral US enforcement of the FCPA in its current manifestation, this pattern should be scrutinized by the legitimacy standards established by GAL scholars and assessed on the basis of how it functions to

68 Oded Löwenheim, "Examining the State: a Foucauldian perspective on international 'governance indicators'”' (2008) 29:2 Third World Q, online: <http://search.proquest.com.ezproxy.library.yorku.ca/docview/219792448/140D63476D75B5EE 918/2?accountid=15182>; Kevin Davis et al, eds, Governance by Indicators: Global Power through Classification and Rankings (Law And Global Governance, 2012).

69 Jeffrey L Dunoff \& Joel P Trachtman, Ruling the World?: Constitutionalism, International Law, and Global Governance (Cambridge University Press, 2009).

${ }^{70}$ Benedict Kingsbury, Nico Krisch \& Richard Stewart, "The Emergence of Global Administrative Law" (2005) 68:3 Law Contemp Probl 15. 
shape markets as well as legal norms in global business regulations and anti-corruption policies alike.

\section{Agenda for Further Research}

In sum, and at the very least, US enforcement of the FCPA may be a case of smoke with no fire: despite the appearance of vigorous enforcement in the context of the global regime, US enforcement of the FCPA reflects specifically American political imperatives. It offers the sheen of activity but very little efficacy to curbing corruption on a global scale or to reducing in a meaningful way the harmful effects of corruption in the daily life of ordinary people. And yet extraterritorial enforcement of the FCPA by the United States remains a crucial component of the global governance of corruption in the $21^{\text {st }}$ century. By extending the scope and reach of U.S. domestic legislation into the global regulatory environment and into other sovereign territories, this practice raises broader questions concerning power, legitimacy, cooperation, efficacy, and national interest in global governance and International Relations, generally. New avenues of interdisciplinary research among international lawyers, political scientists, and scholars of International Relations are needed to pursue these questions.

In the post-Cold War 1990s, interdisciplinary International Law/International Relations (IL/IR) scholarship emerged to explore the various connections among power, interests, institutions, norms, and law increasingly in evidence world politics in those years ${ }^{71}$. During a time of unprecedented legalization in international institutions, research specifically on compliance with international law (under what conditions are states more or less likely to comply with their international legal commitments?) introduced new ways of thinking about international cooperation and also promoted a broadly liberal normative concern for improving cooperative outcomes through compliance with international law in a variety of issue areas ${ }^{72}$. More recently,

\footnotetext{
${ }^{71}$ Anne-Marie Slaughter, Anthony Tulumello \& Stepan Wood, "International Law and International Relations Theory: A New Generation of Interdisciplinary Scholarship" (1998) 92 Am J Int Law.

${ }^{72}$ Kal Raustiala \& Anne-Marie Slaughter, "International Law, International Relations and Compliance" in Beth A Simmons, Walter E (Emmanuel) Carlsnaes \& Thomas Risse, eds, Handb Int Relat Ed Walter Carlsnaes Thomas (London: Sage Publications, 2002); Beth Simmons, "International Law and State Behavior: Commitment and Compliance in International Monetary Affairs" (2000) 94:4 Am Polit Sci Rev 819; Abram Chayes \& Antonia Handler Chayes, The New Sovereignty:
} 
interdisciplinary IL/IR research continues to shed light on the reasons why states behave the way they do in their relations with one another and with international institutions, explaining, for instance, how the delegation of legal authority to international judicial institutions influences global and domestic politics ${ }^{73}$.

While the study of compliance remains a central preoccupation of international legal scholarship, and is perhaps its fastest growing subfield ${ }^{74}$, scholars are also turning their attention to new developments in extra-territorial jurisdiction, the application of which by powerful actors has become increasingly frequent. ${ }^{75}$ So far the literature is hampered by two large gaps: a lack of attention to the extraterritorial enforcement of anti-corruption law and a dearth of attention from political scientists and scholars of International Relations. Anti-corruption politics remain an as yet untapped subject of study on ETJ, one which is particularly ripe for an IR approach. An IR approach to anti-corruption law raises political questions about the extraterritorial enforcement of the FCPA. Active and vigorous enforcement of the FCPA raises questions, for example, about the inconsistent application of extraterritorial jurisdiction across issue areas. Why the intense focus on bribery and corruption, but a reluctance to promote extraterritorial application of human rights laws, labor standards, environmental regulations and other areas?76 As the U.S. Supreme Court has been scaling back extraterritorial jurisdiction driven by private litigants - the recent Morrison (securities law) and Kiobel (human rights) cases, for example - why have government agencies enforcing the FCPA been expanding its jurisdictional scope to include non-US based activities by non-US actors?

Although as a matter of law, the application of the FCPA across borders is presented as an issue of jurisdiction, the underlying matter is that of state interests and of state power. Implicating as it does competing claims to authority, and challenges to state sovereignty, ETJ in US anti-corruption

Compliance With International Regulatory Agreements (Harvard University Press, 1998); Judith L Goldstein et al, eds, Legalization and World Politics (MIT Press, 2001); Edith Brown Weiss \& Harold K Jacobson, eds, Engaging Countries: Strengthening Compliance with International Environmental Accords, Global environmental accords series (Cambridge, Mass: MIT Press, 1998).

${ }^{73}$ Karen J Alter, The new terrain of international law: courts, politics, rights (Princeton: Princeton University Press, 2014).

${ }^{74}$ Robert Howse \& Ruti Teitel, "Beyond Compliance: Rethinking Why International Law Really Matters" (2010) 1:2 Glob Policy 127.

75 Danielle Ireland-Piper, "Extraterritorial Criminal Jurisdiction: Does the Long Arm of the Law Undermine the Rule of Law" (2012) 13 Melb J Int Law 122; Tonya L Putnam, "Courts Without Borders: Domestic Sources of U.S. Extraterritoriality in the Regulatory Sphere" (2009) 63:3 Int Organ 459; Samantha Besson, "The Extraterritoriality of the European Convention on Human Rights: Why Human Rights Depend on Jurisdiction and What Jurisdiction Amounts to" (2012) 25:4 857; Arnell, supra note 5.

${ }^{76}$ The export of its standards by the U.S. requires further study. Areas of interest might include sports anti-doping (through the U.S. Anti-Doping Agency), telecommunications standards, and others. 
enforcement is an important topic for further study. As a key case of ETJ in contemporary global politics, the FCPA - the subject of wide-ranging and intensive scrutiny in international legal and business scholarship - deserves greater attention from political scientists. 
Alter, Karen J. The new terrain of international law: courts, politics, rights (Princeton: Princeton University Press, 2014).

Arnell, Paul. Law Across Borders: The Extraterritorial Application of United Kingdom Law (New York: Routledge, 2012).

Brown Weiss, Edith \& Harold K Jacobson, eds. Engaging Countries: Strengthening Compliance with International Environmental Accords, Global environmental accords series (Cambridge, Mass: MIT Press, 1998).

Busch, Marc L. Trade Warriors: States, Firms, and Strategic Trade Policy in High-Technology Competition (Cambridge: Cambridge University Press, 1999).

Chayes, Abram \& Antonia Handler Chayes. The New Sovereignty: Compliance With International Regulatory Agreements (Harvard University Press, 1998).

Davis, Kevin et al, eds. Governance by Indicators: Global Power through Classification and Rankings (Law And Global Governance, 2012).

Deming, Stuart. The Foreign Corrupt Practices Act and the New International Norms, 2nd Edition ed (American Bar Association, 2011).

Dunoff, Jeffrey L \& Joel P Trachtman. Ruling the World?: Constitutionalism, International Law, and Global Governance (Cambridge University Press, 2009).

Easterly, William. The white man's burden (London: Penguin Books, 2007).

Goldstein, Judith L et al, eds. Legalization and World Politics (MIT Press, 2001).

Koehler, Mike. The Foreign Corrupt Practices Act in a New Era (Edward Elgar Publishing, 2014).

Krugman, Paul R \& Alistair Smith, eds. Empirical Studies of Strategic Trade Policy (Chicago and London: University of Chicago Press, 1994).

Milanovic, Marko. Extraterritorial Application of Human Rights Treaties (Oxford University Press, 2011).

Noonan, John Thomas. Bribes (Macmillan, 1984).

Raustiala, Kal. Does the constitution follow the flag?: The evolution of territoriality in American law (Oxford: Oxford University Press, 2009).

Rose-Ackerman, Susan. Corruption and government: causes, consequences, and reform (Cambridge: Cambridge University Press, 1999).

Ryngaert, Cedric. Jurisdiction in International Law (Oxford University Press, 2008).

Vannucci, Alberto \& Donatella della Porta. Corrupt Exchanges: Actors, Resources, and Mechanisms of Political Corruption (New York: Aldine Transaction, 1999). 
Walzenbach, GPE. Co-ordination in Context: Institutional Choices to Promote Exports (Aldershot, UK: Ashgate, 1998).

2000, Milliet-Einbinder Martine. "Writing Off Tax Deductibility. OECD Observer, May 26. <http://www.oecdobserver.org/news/fullstory.php/aid/245” (2001) 21 Print May.

Ashcroft, John \& John Ratcliffe. "The Recent and Unusual Evolution of an Expanding Fcpa” (2012) 26:1 Notre Dame J Law Ethics Public Policy 25.

Ashe, Daniel Patrick. "The Lengthening Anti-Bribery Lasso of the United States: The Recent Extraterritorial Application of the U. S. Foreign Corrupt Practices Act" (2005) 73:6 Fordham Law Rev 2897.

Bartle, Sarah, Chris Chamberlain \& Brian Wohlberg. "Foreign Corrupt Practices Act" (2014) 51:4 Am Crim Law Rev 1265.

Bernstein, Steven. "Legitimacy in intergovernmental and non-state global governance" (2011) 18:1 Rev Int Polit Econ 17.

Besson, Samantha. "The Extraterritoriality of the European Convention on Human Rights: Why Human Rights Depend on Jurisdiction and What Jurisdiction Amounts to" (2012) 25:4 857.

Brassett, James \& Eleni Tsingou. "The Politics of Legitimate Global Governance” (2011) 18:1 Rev Int Polit Econ 1.

Bray, Chad. "Morgan Stanley Ex-Official in China Sentenced to 9 Months in Prison", Wall Str J (17 August 2012), online:

<http://online.wsj.com/articles/SB10000872396390444508504577593950506343444>.

Casino, Bruce J \& Scott Maberry. "FCPA, Due Process, and Jurisdictional Overreach by the DOJ and SEC" (2013) 13:3 Crim Litig 5.

Chaffee, Eric C. "From Legalized Business Ethics to International Trade Regulation: The Role of the Foreign Corrupt Practices Act and Other Transnational Anti-Bribery Regulations in Fighting Corruption in International Trade" (2013) 65 Mercer Law Rev 701.

Garay-Salamanca, Luis. "Institutional impact of criminal networks in Colombia and Mexico" (2012) 57:2 Crime Law Soc Change 177.

Gibney, Mark. “Toward a Theory of Extraterritoriality” (2010) 95 Minn Law Rev Headnotes 81.

Groenendijk, Nico. "A principal-agent model of corruption" (1997) 27:3-4 Crime Law Soc Change 207.

Gutterman, Ellen. "Corruption in the Global Economy” in Greg Anderson \& Christopher John Kukucha, eds, Int Polit Econ (Don Mills, Ont.: Oxford University Press Canada, forthcoming).

Gutterman, Ellen. "The Legitimacy of Transnational NGOs: Lessons from the Experience of Transparency International in Germany and France” (2014) 40 Rev Int Stud 391. 
Gutterman, Ellen. "Easier Done Than Said: Transnational Bribery, Norm Resonance, and the Origins of the US Foreign Corrupt Practices Act” (2015) 11:1 Foreign Policy Anal 109.

Hansberry, Heidi L. "In Spite of Its Good Intentions, the Dodd-Frank Act Has Created an FCPA Monster" (2012) 102:1 J Crim Law Criminol 195.

Heilbrunn, John R. “Oil and Water? Elite Politicians and Corruption in France” (2005) 37:3 Comp Polit 277.

Holt, Ron. "Beyond the Tribe: Patron-Client Relations, Neopatrimonialism in Afghanistan" (2012) 38:1 Mil Intell Prof Bull 27.

Howse, Robert \& Ruti Teitel. "Beyond Compliance: Rethinking Why International Law Really Matters” (2010) 1:2 Glob Policy 127.

Ireland-Piper, Danielle. "Extraterritorial Criminal Jurisdiction: Does the Long Arm of the Law Undermine the Rule of Law" (2012) 13 Melb J Int Law 122.

Isaacson, Kristin. "Minimizing the Menace of the Foreign Corrupt Practices Act" (2014) 2014 Univ Ill Law Rev 597.

Kaczmarek, Sarah C \& Abraham L Newman. "The Long Arm of the Law: Extraterritoriality and the National Implementation of Foreign Bribery Legislation" (2011) 65:4 Int Organ 745.

Khan, Mushtaq H. "Patron-Client networks and the economic effects of corruption in Asia" (1998) 10:1 Eur J Dev Res 15.

Kingsbury, Benedict, Nico Krisch \& Richard Stewart. "The Emergence of Global Administrative Law" (2005) 68:3 Law Contemp Probl 15.

Löwenheim, Oded. "Examining the State: a Foucauldian perspective on international 'governance indicators"” (2008) 29:2 Third World Q, online:

<http://search.proquest.com.ezproxy.library.yorku.ca/docview/219792448/140D63476D75B5EE 918/2?accountid=15182>.

Matthews, Christopher M. "Former Morgan Stanley Exec Gets Nine Months in FCPA Case", Wall Str J (17 August 2012), online: <http://blogs.wsj.com/corruption-currents/2012/08/17/formermorgan-stanley-exec-gets-nine-months-in-fcpa-case/>.

Putnam, Tonya L. "Courts Without Borders: Domestic Sources of U.S. Extraterritoriality in the Regulatory Sphere" (2009) 63:3 Int Organ 459.

Raustiala, Kal \& Anne-Marie Slaughter. "International Law, International Relations and Compliance" in Beth A Simmons, Walter E (Emmanuel) Carlsnaes \& Thomas Risse, eds, Handb Int Relat Ed Walter Carlsnaes Thomas (London: Sage Publications, 2002).

Rose-Ackerman, Susan. "International anti-Corruption Policies and the U.S. National Interest" (2013) 107 Am Soc Int Law Proc 254.

Shelley, Louise I. "Transnational Organized Crime: The New Authoritarianism" in H Richard Friman \& Peter Andreas, eds, Illicit Glob Econ State Power (Lanham, Md: Rowman \& Littlefield Pub., 1999). 
Shelley, Louise I. "The Unholy Trinity: Transnational Crime, Corruption, and Terrorism" (2005) 11:2 Brown J World Aff 101.

Simmons, Beth. "International Law and State Behavior: Commitment and Compliance in International Monetary Affairs” (2000) 94:4 Am Polit Sci Rev 819.

Slaughter, Anne-Marie, Anthony Tulumello \& Stepan Wood. "International Law and International Relations Theory: A New Generation of Interdisciplinary Scholarship" (1998) 92 Am J Int Law.

Stephan, Paul. "The Political Economy of Extraterritoriality” (2013) 1:1 Polit Gov 92.

Thomas, Cortney C. "Foreign Corrupt Practices Act: A Decade of Rapid Expansion Explained, Defended, and Justified” (2009) 29 Rev Litig 439.

Wilson, Natasha N. "Pushing the limits of jurisdiction over foreign actors under the Foreign Corrupt Practices Act” (2014) 91:4 Wash Univ Law Rev 1063+.

Zhan, Jing. "Filling the gap of formal institutions: the effects of Guanxi network on corruption in reform-era China” (2012) 58:2 Crime Law Soc Change 93.

Blattman, Chris. "Corruption and development: Not what you think?", (5 November 2012), online: Chris Blattman Int Dev Polit Econ Policy <http://chrisblattman.com/2012/11/05/corruption-anddevelopment-not-what-you-think/>.

Breuer, Lanny A. Speech at the New York City Bar Association (New York, 2012).

Bright, Claire. The Implications of the Kiobel v. Royal Dutch Petroleum Case for the Exercise of Extraterritorial Jurisdiction, SSRN Scholarly Paper ID 2364707 (Rochester, NY: Social Science Research Network, 2013).

Calkins, Laurel Brubaker. "Ex-KBR CEO Stanley Gets 2 1/2 Years in Prison for Foreign Bribes", (24 February 2012), online: Bloomberg <http://www.bloomberg.com/news/2012-02-23/ex-kbr-ceoalbert-stanley-gets-30-month-prison-term-in-nigeria-bribe-case.html>.

Cooley, Alexander \& Jason Sharman. The Price of Access: Transnational Corruption Networks in Central Asia and Beyond (San Francisco, CA, 2013).

DOJ. "FCPA and Related Enforcement Actions", (2014), online: U S Dep Justice <http://www.justice.gov/criminal/fraud/fcpa/cases/a.html>.

Fisher, Alice S. Prepared Remarks for the American Bar Association National Institute on the Foreign Corrupt Practices Act, Washington DC (US Department of Justice, 2006).

Fons, Randall J, Brian Neil Hoffman \& Tiffany A Rowe. The SEC Speaks: Reflections and Enforcement Initiatives in 2013 (Morrison Foerster, 2013).

Garrett, Laurie. "The Challenge of Global Health", Foreign Aff (2007) 14.

Kaufmann, Daniel. "Corruption And The Global Financial Crisis”, (27 January 2009), online: Forbes <http://www.forbes.com/2009/01/27/corruption-financial-crisis-businesscorruption09_0127corruption.html>. 
Koehler, Mike. Big, Bold, and Bizarre: The Foreign Corrupt Practices Act Enters a New Era, SSRN Scholarly Paper ID 1971021 (Rochester, NY: Social Science Research Network, 2011).

Koehler, Mike. “Total Agrees To Pay \$398 Million To Resolve Its FCPA Scrutiny”, (30 May 2013), online: FCPA Profr <http://www.fcpaprofessor.com/total-agrees-to-pay-398-million-to-resolve-itsfcpa-scrutiny>.

Koehler, Mike. “Total'ly Milking The FCPA Cash Cow?”, (3 June 2013), online: FCPA Profr $<$ http://www.fcpaprofessor.com/totally-milking-the-fcpa-cash-cow>.

Koehler, Mike. "FCPA 101”, online: FCPA Profr <http://www.fcpaprofessor.com/fcpa-101>.

OECD. “OECD Working Group on Bribery Elects New Chair”, (7 August 2013), online: OECD Better Policies Better Lives <http://www.oecd.org/daf/anti-bribery/oecd-working-group-on-briberyelects-new-chair.htm>.

Office of Public Affairs. Executive Sentenced to 15 Years in Prison for Scheme to Bribe Officials at State-Owned Telecommunications Company in Haiti (US Department of Justice, 2011).

Rakoff, Jed S. "The Financial Crisis: Why Have No High-Level Executives Been Prosecuted?", N Y Rev Books (9 January 2014), online:

<http://www.nybooks.com/articles/archives/2014/jan/09/financial-crisis-why-no-executiveprosecutions/>.

Ross, Lauren Ann. "Using foreign relations law to limit extraterritorial application of the Foreign Corrupt Practices Act", Duke Law J (November 2012) 445+.

The World Bank. "The Costs of Corruption”, (8 April 2004), online:

<http://go.worldbank.org/LJA29GHA80>.

Transparency International. "What we do", (2013), online: Transpar Int - Glob Coalit Corrupt <http://www.transparency.org/whatwedo>.

Transparency International. "Bribe Payers Index: Overview”, (2013), online: Transpar Int - Glob Coalit Corrupt<http://www.transparency.org/research/bpi/overview>.

Transparency International. “What is Corruption?", online: Transpar Int - Glob Coalit Corrupt <https://www.transparency.org/what-is-corruption>.

United Nations Office on Drugs and Crime. "United Nations Convention Against Corruption”, online: <https://www.unodc.org/unodc/en/treaties/CAC/>.

Urofsky, Philip, ed. FCPA Digest of Cases and Review Releases Relating to Bribes to Foreign Officials under the Foreign Corrupt Practices Act of 1977 (Shearman \& Sterling LLP, 2014).

US Department of Justice. "Foreign Corrupt Practices Act", online:

<http://www.justice.gov/criminal-fraud/foreign-corrupt-practices-act>.

US DOJ, Criminal Division \& Enforcement Division US SEC. FCPA: A resource Guide to the U.S. Foreign Corrupt Practices Act (2012). 
US SEC. "SEC Enforcement Actions: FCPA Cases", (2014), online: US Secur Exch Comm <http://www.sec.gov/spotlight/fcpa/fcpa-cases.shtml>.

Vardi, Nathan. "The Bribery Racket", Forbes (7 June 2010), online: <http://www.forbes.com/global/2010/0607/companies-payoffs-washington-extortionmendelsohn-bribery-racket.html>.

Weissmann, Jordan. "The Corruption Law That Scares the Bejesus Out of Corporate America”, (25 April 2012), online: The Atlantic <http://www.theatlantic.com/business/archive/2012/04/thecorruption-law-that-scares-the-bejesus-out-of-corporate-america/256314/\#>.

Wirz, Severin. Private Settlements, Public Concerns: Judicial Scrutiny of Deferred Prosecution Agreements (TRACE International, 2013).

World Economic Forum. "Global Agenda Council on Anti-Corruption \& Transparency 2013", online: Glob Agenda Counc Anti-Corrupt Transpar 2013 World Econ Forum <http://www.weforum.org/content/global-agenda-council-anti-corruption-transparency-2013>.

"UNCAC Coalition | Civil Society", online: <http://uncaccoalition.org/en_US/>.

"First G20 Anti-Corruption Working Group Meeting held in Istanbul", online: G20 <https://g20.org/first-g20-anti-corruption-working-group-meeting-held-in-istanbul/>.

Table 1 - Corporate Enforcement Actions (DOJ \& SEC), 2002-2013

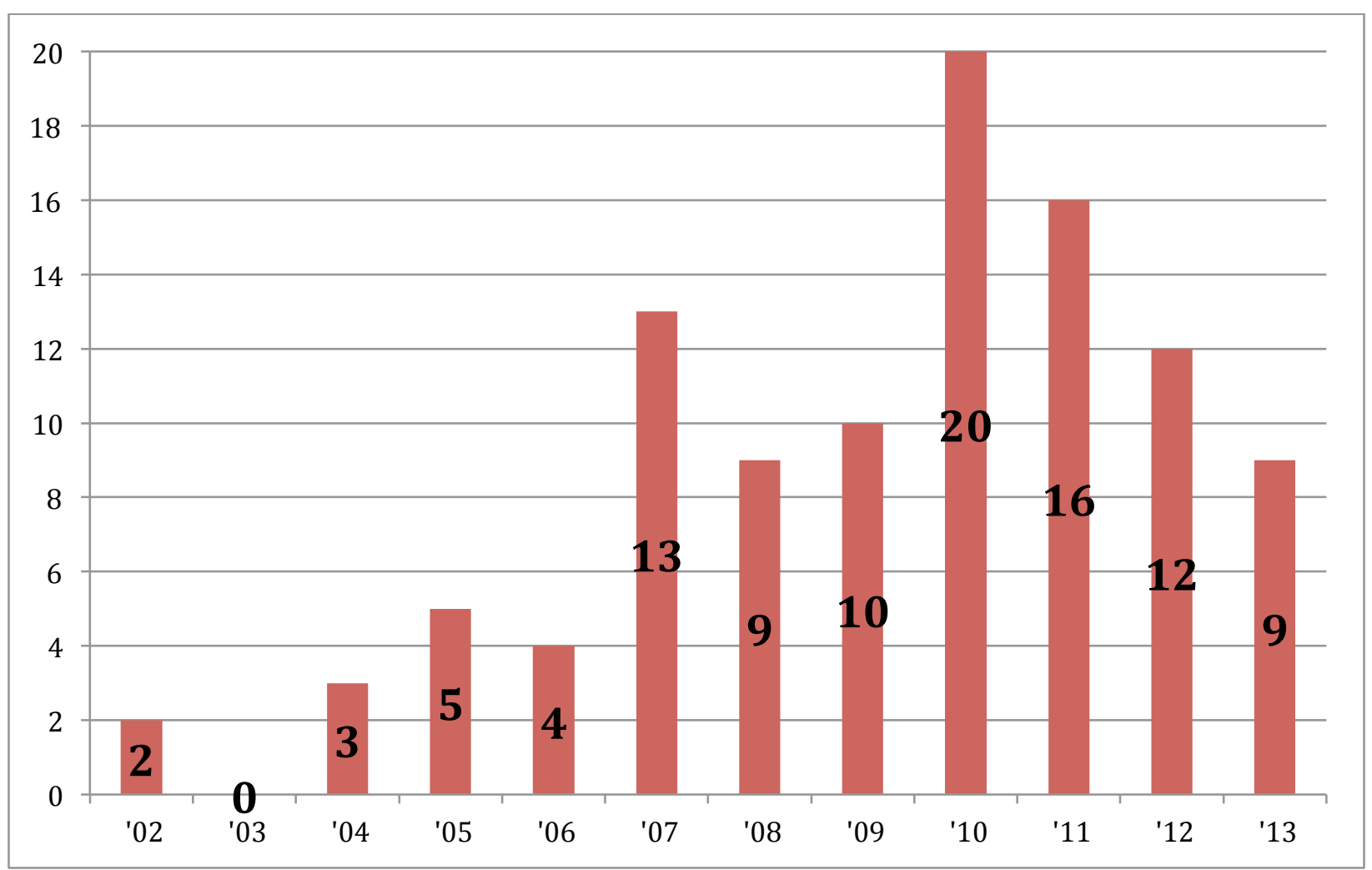


Table 2 - Individuals Charged, 2002 - 2013

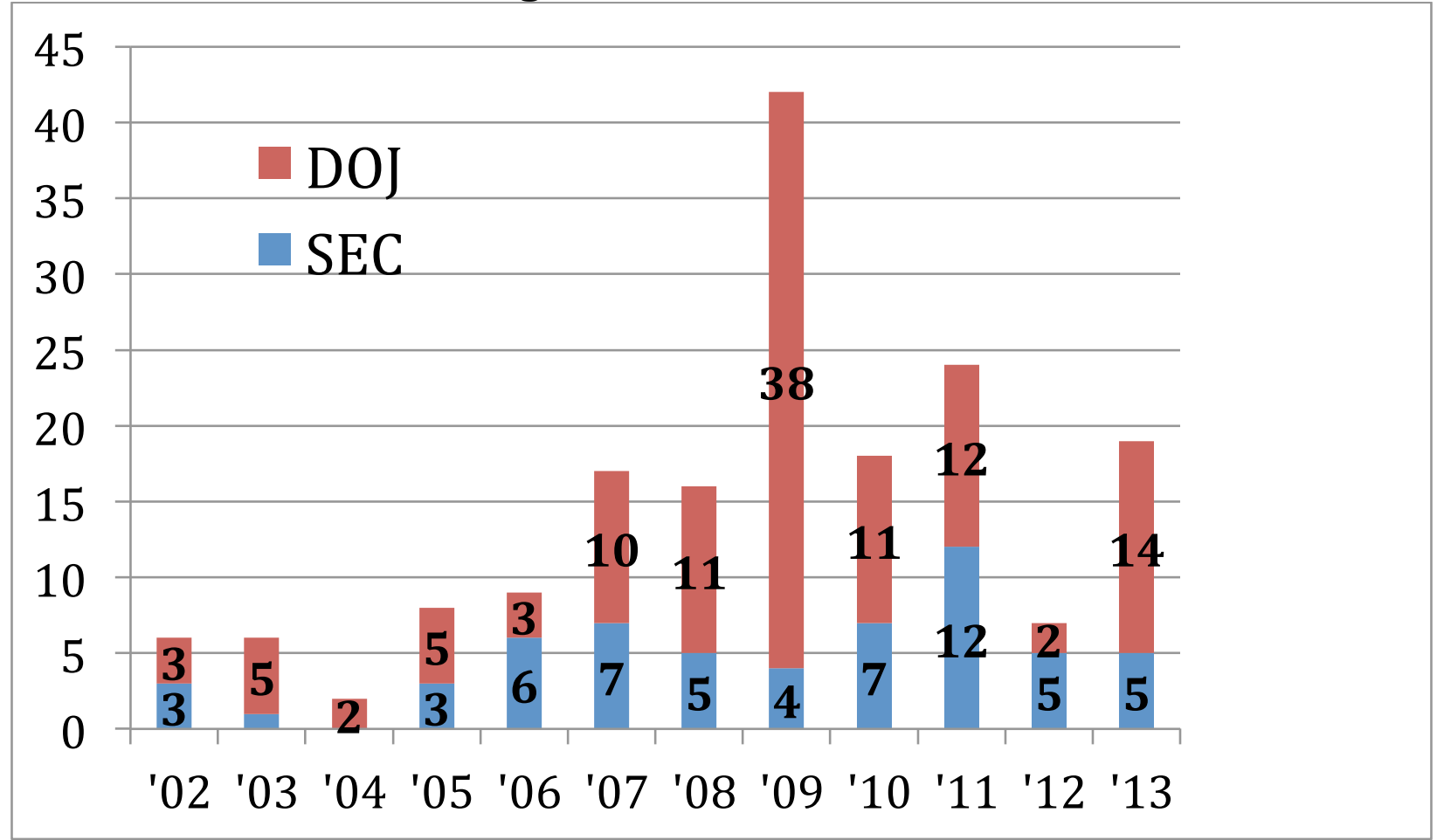

Table 3 - Criminal and Civil Corporate Fines Imposed, 2004-2013



Table 4 - Average Corporate Penalties, 2004-2013 


\section{Amount in Millions (\$)}

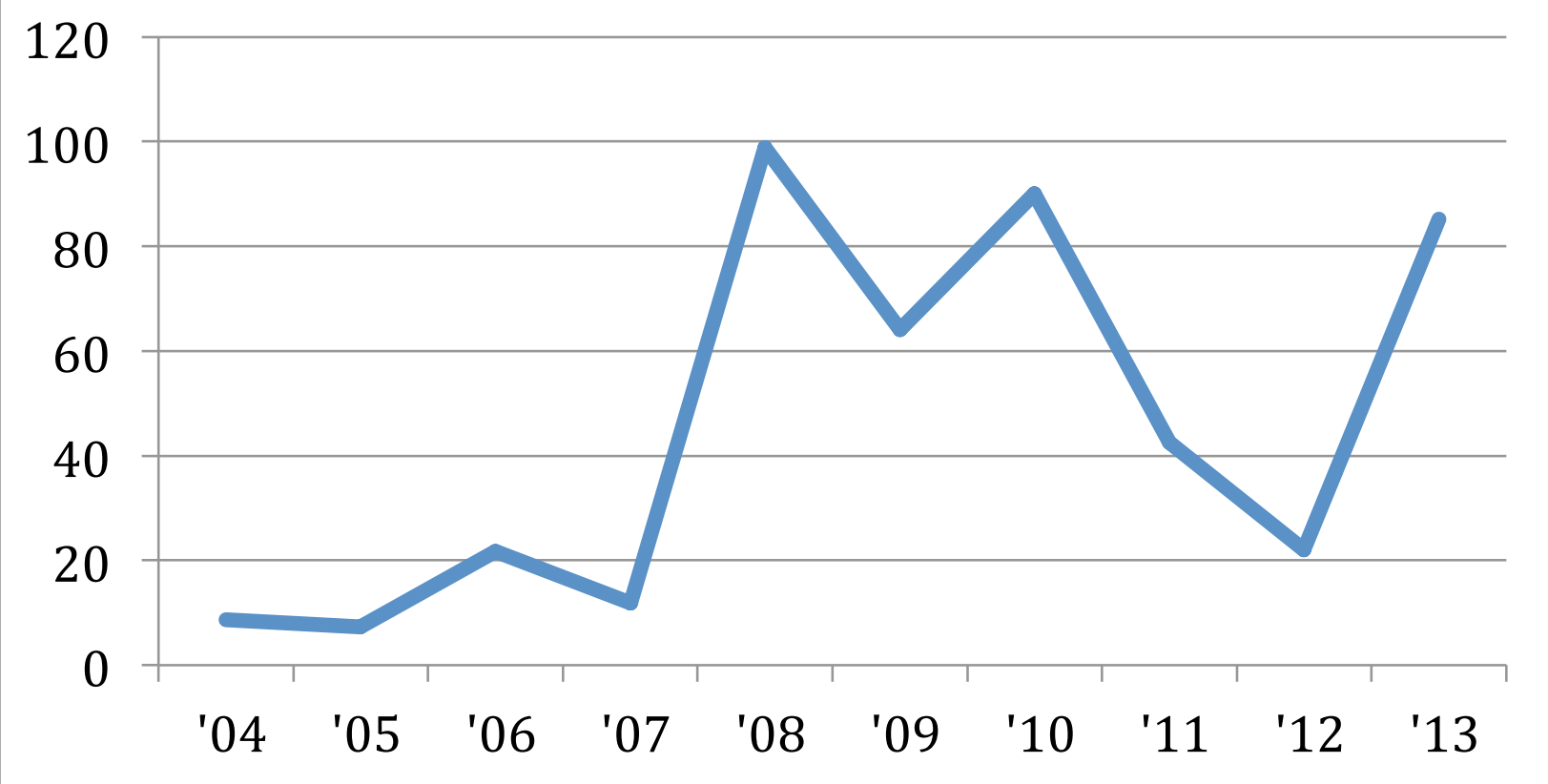

